Marek Czajkowski

\title{
Prawo kosmiczne a bezpieczeństwo międzynarodowe - stan obecny i możliwe kierunki ewolucji
}

Abstract: The article covers some issues related to international security that are present in space law as its underdeveloped norms may have great impact on the political sphere. It therefore first depicts the origins of space law and its main provisions, paying special attention to international security related issues. Then it takes to the main subject that is an assessment of an evolution of space law in the future with particular attention paid to ongoing militarization of space.

KEYWORDS: international relations, international security, outer space, space law, militarization of space

\section{Wprowadzenie}

Od sześciu dekad ludzkość prowadzi w przestrzeni kosmicznej coraz bardziej ożywioną działalność, która doprowadzila do powstania wielu technologii przynoszących znaczne korzyści $w$ różnych dziedzinach. Upowszechnily się one do tego stopnia, że wiele $\mathrm{z}$ nich stalo się wręcz niezbędnymi do funkcjonowania państw i spoleczeństw. W bliższej i dalszej perspektywie przewiduje się rozwój istniejących i powstanie kolejnych możliwości wynikających z zastosowania systemów kosmicznych. W związku 
z tym istnieje oczywista potrzeba regulowania tej aktywności za pomocą instrumentów prawnych, zarówno leżących w gestii państw, jak i międzynarodowych.

Pierwsza $z$ tych płaszczyzn wydaje się relatywnie prosta - poszczególne kraje regulują działalność podporządkowanych im jednostek i osób prawnych w ramach swojej jurysdykcji. Dotyczy to przede wszystkim „ziemskiego” komponentu dzialalności kosmicznej, czyli:

1. organizacji i przedsiębiorstw realizujących przynajmniej część swojej aktywności w kosmosie;

2. obywateli oraz przedsiębiorstw i organizacji będących adresatem oferowanych przez sektor kosmiczny usług oraz dóbr;

3. struktur państwowych, które wspomagają realizację swych funkcji, wykorzystując możliwości, które dają im systemy kosmiczne.

Druga kwestia, międzynarodowa regulacja działalności kosmicznej, jest bardziej skomplikowana. Dotyczy ona bowiem, po pierwsze, złożonych interakcji pomiędzy państwami realizującymi zadania w ramach swych funkcji zewnętrznych, w szczególności w związku $z$ bezpieczeństwem narodowym, a po drugie, regulacji działalności o charakterze transgranicznym realizowanej przez podmioty poddane wladzy poszczególnych krajów. Są to problemy bardzo trudne, ponieważ ze względu na charakterystyczne cechy przestrzeni kosmicznej jedna z podstawowych instytucji prawa międzynarodowego, którą jest granica, nie istnieje w sposób porównywalny do przestrzeni ${ }_{n}$ ziemskiej”. Co więcej, pojawia się problem styku obu przestrzeni regulacji, ponieważ prawo międzynarodowe wciąż nie zdefiniowało granicy pomiędzy obszarem suwerenności państwa a przestrzenią kosmiczną.

Już ten podstawowy problem, czyli określenie granic obszaru, na którym obowiązują określone uregulowania, wskazuje na istotną cechę prawa dotyczącego działalności kosmicznej, czyli na niedostateczny rozwój systemu norm. Wprawdzie istnieją pewne zasady i dorobek prawny w postaci konwencji międzynarodowych, lecz nie wyjaśniają one zawartości podstawowych pojęć w sposób choćby w przybliżeniu tak wyraźny, jak to ma miejsce w stosunku do „ziemskiego" prawa międzynarodowego opartego na pojęciach granicy, terytorium i suwerenności z nimi związanej.

Jednocześnie $z$ wielu powodów pojawia się coraz większe zapotrzebowanie na unormowania w interesującej nas materii. Po pierwsze, rośnie znaczenie ekonomiczne i spoleczne systemów satelitarnych. Po drugie, przestrzeń kosmiczna jest coraz bardziej zaśmiecona, co zagraża jej przyszłemu wykorzystaniu, a zatem korzyściom $z$ niego wynikającym. Po trzecie zaś, rośnie jej znaczenie z punktu widzenia bezpieczeństwa narodowego i międzynarodowego. 
Niniejszy artykuł koncentruje się na kwestiach bezpieczeństwa międzynarodowego w prawie kosmicznym, ponieważ $w$ tej dziedzinie słabo rozwinięte normy moga stanowić największy problem o potencjalnie dużej wadze politycznej. Przybliżymy zatem w pierwszej kolejności genezę prawa kosmicznego, jego podstawowe pojęcia oraz główne postanowienia, akcentując interesujący nas wymiar bezpieczeństwa międzynarodowego. Następnie rozważymy perspektywę ewolucji prawa kosmicznego, w szczególności z punktu widzenia potencjalnie bardzo istotnej kwestii, jaką jest możliwa dalsza militaryzacja przestrzeni kosmicznej.

\section{Geneza prawa kosmicznego}

Rozpatrując problem powstania i ewolucji prawa kosmicznego, należy na wstępie zwrócić uwagę na charakterystykę przestrzeni kosmicznej z punktu widzenia wykorzystania jej przez człowieka, ponieważ to najbardziej rzutuje na adekwatność wielu tradycyjnych, podstawowych instytucji prawa międzynarodowego. Można wyjaśnić tę stosunkowo zawiłą kwestię, korzystając $z$ analogii do wcześniejszego rozwoju prawa morza, a następnie prawa lotniczego.

Od czasu przejścia człowieka od kultury nomadycznej do tworzenia spoleczeństw osiadłych, terytorium, czyli określony obszar Ziemi, jest podstawą bytu grup ludzi oraz jednym z glównych przedmiotów ich wzajemnych relacji. Władanie określonym terytorium jest zatem dziś podstawą funkcjonowania większości spoleczeństw świata. Wytworzyły się wobec tego różnorodne formy zabezpieczania władztwa terytorialnego, którego współczesną formą jest suwerenność państwowo-terytorialna. Ponieważ człowiek jako gatunek żyje na lądzie stałym, wyznaczenie tu granic obszarów władania różnych grup jest czymś naturalnym, ten proces przebiega od tysięcy lat. A zatem sposoby i formy delimitacji obszarów lądowych są istotnymi elementami dorobku ludzkości w procesie tworzenia prawa regulującego zasady funkcjonowania grup $\mathrm{i}$ ich relacji wzajemnych. Granica, jako coś fizycznego i konkretnego jest silnie zakorzeniona w świadomości spoleczeństw oraz w systemach prawnych i politycznych.

Rozciągając panowanie ludzkości na obszary morskie, ustanowiono, w trakcie długiego i złożonego procesu ewolucji, pewne reguly z tym związane. Polegają one na rozciągnięciu suwerenności państwowej na niektóre obszary morskie przy jednoczesnym uznaniu reszty za przestrzeń $z$ nazwy będącą rzeczą wspólną, $w$ istocie jednak traktowaną jak rzecz niczyja, czyli niepodlegająca niczyjej suwerenności, otwarta na swobodną eksploatację. Nie obyło się to zresztą bez dyskusji i sporów, do dziś kwestia zasięgu suwerenności państwowej i roszczenia z tym związane są istotnym problemem 
w stosunkach międzynarodowych. W każdym razie mamy do czynienia $z$ rozciąganiem władztwa terytorialnego ukształtowanego na lądzie na obszary morskie, jako swego rodzaju przedłużenie lądu przy pomocy podobnych mechanizmów prawnych. Z kolei wraz z rozwojem lotnictwa, w chwili kiedy ludzie nauczyli się wykorzystywać przestrzeń powietrzną, rozciągnięto zasady dotyczące suwerenności ponad terytorium państw i ich mórz terytorialnych. Tym sposobem nadano suwerenności trzeci wymiar, zgodnie $\mathrm{z}$ tradycyjną zasadą cuius est solum, eius est usque ad coelum ${ }^{1}$.

W przypadku przestrzeni kosmicznej, nie da się jednak rozciągnąć tych samych zasad poprzez kolejne analogie, których użyteczność jest tu ograniczona. Rzecz w tym, że obiekty kosmiczne, przynajmniej według dzisiejszego stanu wiedzy i techniki, by „utrzymać się" w kosmosie, muszą poruszać się ze znaczną prędkością po krzywych zamkniętych, które zawierają się w płaszczyznach przechodzących przez środek Ziemi, zwanych orbitami. W większości przypadków obiekty kosmiczne, czyli sztuczne satelity Ziemi, okrążają cały świat, znajdując się kolejno nad terytoriami wielu państw. A zatem tradycyjna, przywiązana do terytorium suwerenność po niebiosa, nie daje się w kosmosie utrzymać, właśnie ze względu na ciągły ruch satelitów. Inaczej mówiąc, podczas gdy statek bądź samolot może manewrować względnie swobodnie i unikać pewnych obszarów na ziemi/morzu lub ponad nimi, obiekt orbitalny nie ma takiej możliwości.

Ta cecha satelitów została zidentyfikowana jako źródło potencjalnie poważnych problemów prawnych już u zarania ery kosmicznej. USA i ZSRR wcześnie dostrzegły wielki potencjał użyteczności przestrzeni pozaziemskiej, szczególnie w kontekście bezpieczeństwa narodowego, stąd w obu państwach skierowano znaczne środki na rozwój odpowiednich technologii. W Stanach Zjednoczonych administracja prezydenta Eisenhowera miała przede wszystkim nadzieję, że systemy kosmiczne dostarczą informacji wywiadowczych dotyczących owianego tajemnicą ZSRR, a szczególnie jego potencjalu strategicznego. W związku z tym Amerykanie od początku dążyli do ustanowienia zasady wolności przestrzeni kosmicznej, na podobieństwo zasady wolności mórz. Zastanawiano się jednak, jaka będzie reakcja ZSRR na przelot nad jego terytorium amerykańskiego obiektu. W celu "obejścia” tego problemu jeszcze w 1955 r. USA ogłosily, że wprowadzą na orbitę pierwszego sztucznego satelitę Ziemi w ramach Międzynarodowego Roku Geofizycznego². Jako obiekt naukowy i część powszechnego międzynarodowego wysiłku miał stać się swego rodzaju precedensem,

\footnotetext{
1 Łac.: czyja jest ziemia, tego wszystko aż do nieba.
}

2 Zaproponowany przez uczonych amerykańskich wielonarodowy program wspólpracy w badaniach Ziemi, realizowany między 1 VI 1957 a 31 XII 1958 r., objął większość krajów świata, w tym wszystkie kraje socjalistyczne. 
choć oczywiście nie wiedziano, jaka będzie ostatecznie reakcja ZSRR. Z dylematu wybawila Waszyngton partycypująca w tym programie Moskwa, która cztery dni po USA oglosiła podobny zamiar. Dążąc do prestiżowego sukcesu, po kilku nieudanych próbach ZSRR pospiesznie wystrzelił w październiku 1957 r. na orbitę okołoziemską Sputnika 1, który mimo bardzo ubogiej aparatury mógł stanowić namiastkę satelity naukowego. Przebywal on na orbicie trzy miesiące i w trakcie 1440 okrążeń Ziemi nprzeleciał" wielokrotnie nad wszystkimi krajami świata.

Tym sposobem pojawiła się na zasadzie faktów dokonanych zasada, wedle której przestrzeń kosmiczna stała się res communis, w pewnym sensie analogicznie do otwartego morza. Problemem pozostała jednak granica pomiędzy przestrzenią powietrzną pozostającą obszarem suwerenności państwa a otwartym kosmosem. Kwestia ta nie została do dziś uregulowana traktatowo, niemniej jednak nie stanowiła problemu, ponieważ charakterystyki statków kosmicznych i atmosferycznych wpływające na możliwości osiągania przez nie określonych wysokości lotu były od siebie bardzo odległe. Dopiero ewentualne pojawienie się „samolotu kosmicznego", czyli pojazdu zdolnego swobodnie operować i manewrować w obu przestrzeniach i pomiędzy nimi, mogloby zaostrzyć problem. Można to było dostrzec np. w radzieckich obawach w związku z projektem X-20 Dyna-Soar rozwijanym na przełomie lat 50. i 60. XX w. przez USA.

Pierwszą rezolucją ZO ONZ, która dotyczyła przestrzeni kosmicznej, była rezolucja nr 1348 z 13 XII 1958 r. Jej głównym postanowieniem było powołanie Komisji ds. pokojowego wykorzystania przestrzeni kosmicznej (COPUOS ${ }^{3}$ ), ponadto po raz pierwszy użyto stwierdzenia, że ${ }_{n}[\ldots]$ jest wspólnym celem wykorzystanie przestrzeni kosmicznej jedynie w celach pokojowych [... $]^{m 4}$.W 1959 r. status komisji został zmieniony z ad hoc na stały ${ }^{5}$. W 1961 r. ONZ sformułowała pierwsze bardziej szczególowe nzasady przewodnie ${ }^{n}$ w rezolucji nr 1721, która stanowila przede wszystkim, że prawo międzynarodowe rozciąga się na przestrzeń kosmiczną i ciała niebieskie oraz że kosmos i ciała niebieskie nie podlegają zawłaszczeniu przez jakiekolwiek państwo, lecz są otwarte dla eksploracji i wykorzystania zgodnie z prawem międzynarodowym ${ }^{6}$. Rezolucja ta wzywała także wszystkie państwa do rejestracji startów obiektów satelitarnych w COPUOS oraz do wspólpracy międzynarodowej, w szczególności w ramach

3 Commission of the Peaceful Uses of Outer Space.

+ Question of the peaceful use of outer space, Rezolucja ZO ONZ nr 1348 (XIII), 13 XII 1958, http:// www.unoosa.org/pdf/gares/ARES_13_1348E.pdf, 13 I 2017.

5 International co-operation in the peaceful uses of outer space, Rezolucja ZO ONZ nr 1472 (XIV), 12 XII 1959, http://www.unoosa.org/pdf/gares/ARES_14_1472E.pdf, 13 I 2017.

6 International co-operation in the peaceful uses of outer space, Rezolucja ZO ONZ nr 1721 (XVI), 20 XII 1961, http://www.unoosa.org/pdf/gares/ARES_16_1721E.pdf, 13 I 2017. 
Międzynarodowej Organizacji Meteorologicznej oraz Międzynarodowej Unii Telekomunikacyjnej w związku z rysującymi się szerokimi możliwościami wykorzystania systemów kosmicznych dla celów tych organizacji. Mimo że rezolucja ze swej natury nie była aktem rodzącym zobowiązania prawne, jej znaczenie jest nie do przecenienia. Wymienione w niej postanowienia stały się bowiem podstawą wszystkich późniejszych regulacji, w szczególności znaczenie miało inkorporowanie problematyki kosmicznej do prawa międzynarodowego, co w sposób oczywisty zdeterminowało jego dalszy rozwój.

Szybkie postępy w wykorzystaniu kosmosu osiągane w latach 60 . oznaczały rosnące zapotrzebowanie na bardziej szczególowe, a przede wszystkim prawnie wiążące regulacje. Szczególne znaczenie miało to, że wykorzystanie systemów orbitalnych do celów militarnych było coraz szersze i ważniejsze. A zatem z jednej strony obydwa supermocarstwa, a szczególnie bardziej zaawansowane technologicznie USA, zainteresowane były utrzymaniem tego stanu rzeczy, czyli bezpieczeństwem swoich systemów obserwacyjnych i komunikacyjnych. $Z$ drugiej zaś strony supermocarstwa, szczególnie USA $^{7}$, analizowały możliwości opracowania uzbrojenia nadającego się do wykorzystania w przestrzeni kosmicznej zarówno przeciwko systemom satelitarnym drugiej strony, jak i do oddziaływania na powierzchnię Ziemi. Wkrótce jednak okazało się, że nawet w przypadku zastosowania broni masowego rażenia broń kosmiczna będzie niezmiernie droga i z wielu powodów niepraktyczna, nawet jeśli potencjalnie efektywna.

Oba supermocarstwa zdecydowaly się wobec tego sformalizować istniejący stan rzeczy, z jednej strony po to, aby zabezpieczyć dotychczasowe korzyści, z drugiej zaś, by uniknąć potencjalnie groźnego i z pewnością bardzo kosztownego wyścigu zbrojeń w przestrzeni okoloziemskiej, który w dodatku nie przyniósłby wymiernych korzyści. Dlatego też Traktat o przestrzeni kosmicznej z 1967 r. ${ }^{8}$, najważniejszy po dziś dzień dokument regulujący współpracę międzynarodową poza Ziemią, podtrzymuje zasadę, że kosmos jest niepodzielnym dziedzictwem całej ludzkości, ograniczając jego wojskowe zastosowania.

W kolejnych latach podpisano trzy dalsze traktaty, regulujące pewne aspekty wspólpracy międzynarodowej w kosmosie, w pewnym sensie uzupełniające i uszczegóławiające OST. Są to:

7 Por. np.: B. Ziarnick, P. Garretson, Starfleet was closer than you think, "The Space Review”, 16 III 2015, http://www.thespacereview.com/article/2714/1, 16 IV 2015.

8 Pełna nazwa traktatu brzmi: Układ o zasadach rządzących działalnością państw w ramach eksploracji i wykorzystania przestrzeni kosmicznej, lącznie z Księżycem i innymi ciałami niebieskimi (Treaty on Principles Governing the Activities of States in the Exploration and Use of Outer Space, including the Moon and Other Celestial Bodies - w skrócie Outer Space Treaty - OST). Przyjęty rezolucją ZO ONZ nr 2222 (XXI) z 19 XII 1966 r., wszedł w życie 10 X 1967 r. 
- Porozumienie o ratowaniu astronautów, powrocie astronautów i zwrocie obiektów wystrzelonych w przestrzeń kosmiczną ${ }^{9}$, w skrócie Porozumienie ratownicze (Rescue Agreement - ARRA), przyjęte rezolucją ZO ONZ nr 2345 (XXII) 19 XII 1967 r., weszlo w życie 3 XII 1968 r.

- Konwencja o międzynarodowej odpowiedzialności za szkody wyrządzone przez obiekty kosmiczne ${ }^{10}$, w skrócie Konwencja o odpowiedzialności (Liability Convention - LIAB), przyjęta rezolucją ZO ONZ nr 2777 (XXVI) 29 XI 1971 r., weszła w życie 1 IX 1972 r.

- Konwencja o rejestracji obiektów wystrzelonych w przestrzeń kosmiczną ${ }^{11}$,w skrócie Konwencja rejestracyjna (Registration Convention-REG), przyjęta rezolucją ZO ONZ nr 3235 (XXIX) 12 XI 1974 r., weszła w życie 15 IX 1976 r.

W 1979 r. podpisano kolejne porozumienie o przestrzeni kosmicznej, Traktat księżycowy ${ }^{12}$. Wbrew nazwie zawiera on regulację calości tematyki kosmicznej, potwierdzając i rozszerzając, miejscami znacznie, postanowienia OST. Wprawdzie traktat ten wszedł w życie, ale jego sygnatariuszami jest zaledwie 17 państw, z których żadne nie zalicza się do kosmicznych potęg, cztery kolejne państwa traktat jedynie podpisaly, w tym $z$ liczących się jedynie Francja ${ }^{13}$. W związku z powyższym MOON nie ma większego praktycznego znaczenia, pozostając jedynie raczej odległą perspektywą lub też materiałem do dalszych rozważań na temat rozwoju prawa kosmicznego.

\section{Podstawowe zasady prawa kosmicznego}

Prawo kosmiczne, zarówno międzynarodowe, jak też regulacje wewnątrzpaństwowe dotyczące wykorzystania przestrzeni kosmicznej, dotyczy wielu różnych dziedzin działalności czlowieka. Oprócz omawianych w tym artykule dokumentów ONZ istnieje także dwu-i wielostronny dorobek traktatowy. Większość uregulowań i praktycznych zastosowań oraz dorobku orzecznictwa dotyczy sfery cywilnej, związanej z komercyjnym

\footnotetext{
- Agreement on the Rescue of Astronauts, the Return of Astronauts and the Return of Objects Launched into Outer Space.

10 Convention on International Liability for Damage Caused by Space Objects.

1 Convention on Registration of Objects Launched into Outer Space.

12 Pelna nazwa: Porozumienie rządzące działalnością państw na Księżycu i innych ciałach niebieskich (Agreement Governing the Activities of States on the Moon and Other Celestial Bodies, w skrócie Moon Agreement - MOON), przyjęte rezolucją ZO ONZ nr 34/68 z 5 XII 1979 r., weszło w życie 11 VII 1984 r.

13 Stan na dzień 1 I 2017 r., za: Status of International Agreements relating to activities in outer space as at 1 January 2017, COPUS, 23 March 2017, http://www.unoosa.org/documents/pdf/spacelaw/ treatystatus/AC105_C2_2017_CRP07E.pdf, 13 I 2018.
} 
wykorzystaniem przestrzeni kosmicznej. Ponieważ w niniejszym artykule interesujemy się kwestiami bezpieczeństwa międzynarodowego, omówimy główne postanowienia prawa kosmicznego pod tym właśnie kątem.

To, co potocznie nazywamy prawem kosmicznym, nie jest odrębną dziedziną, lecz częścią prawa międzynarodowego publicznego, która ${ }_{n}[. .$.$] odnosi się do przestrzeni$ ponad dolnymi warstwami atmosfery ziemskiej i rządzi postępowaniem w niej"14. Należy jednak także pamiętać o wewnętrznym prawie poszczególnych państw, które z jednej strony może określać granice ich suwerenności, a $\mathbf{z}$ drugiej regulować działalność w przestrzeni kosmicznej podmiotów poddanych władzy danego kraju. W najbardziej ogólnych kategoriach celem prawa kosmicznego jest:

[...] zapewnienie racjonalnego i odpowiedzialnego podejścia do eksploracji i wykorzystania przestrzeni kosmicznej dla dobra i w interesie ludzkości. W tym celu prawo kosmiczne zajmuje się wieloma sprawami, takimi jak ochrona środowiska kosmicznego i ziemskiego, odpowiedzialność za szkody dokonane przez obiekty kosmiczne, rozwiązywanie sporów, zabezpieczenie interesów narodowych, ratowanie astronautów, dzielenie się informacjami na temat potencjalnych zagrożeń w kosmosie, zastosowanie technologii kosmicznych, wspólpraca międzynarodowa ${ }^{15}$.

Jak wspomniano, w ramach systemu ONZ istnieje pięć traktatów międzynarodowych dotyczących prawa kosmicznego, które należy uzupełnić o pięć deklaracji zasad zamieszczonych w rezolucjach $Z \mathrm{O}$ ONZ, pięć dalszych ważnych rezolucji odnoszących się do regulacji współpracy w przestrzeni kosmicznej oraz dwóch dokumentów COPUOS dotyczących kosmicznych śmieci oraz energii nuklearnej w kosmosie ${ }^{16}$. Istnieją także inne akty prawa międzynarodowego, które dotyczą w pewnym zakresie działalności w przestrzeni okołoziemskiej, takie jak np. Traktat o ograniczeniu prób jądrowych ${ }^{17}$. Istnieje także wzmiankowany dorobek wyznaczający dwu-i wielostronną współpracę międzynarodową w badaniu i wykorzystaniu kosmosu, w szczególności związany $z$ telekomunikacją.

$\mathrm{Z}$ punktu widzenia założeń niniejszego artykułu, zorientowanego na bezpieczeństwo międzynarodowe, najistotniejsze i fundamentalne znaczenie ma traktat OST, którego postanowienia stanowią podstawę obowiązującego dziś prawa kosmicznego.

14 Space law, Encyclopaedia Britannica, 27 XII 2017, https://www.britannica.com/topic/spacelaw, 13 I 2018.

15 Educational Curriculum on Space Law, UNOOSA, 2014, s. 9, http://www.unoosa.org/res/oosadod data/documents/2014/stspace/stspace64_0_html/st_space_064E.pdf, 16 I 2018.

16 International Space Law: United Nations Instruments, UNOOSA, May 2017, s. F.

17 Pelna nazwa: Układ o zakazie prób broni nuklearnej w atmosferze, w przestrzeni kosmicznej i pod woda (Treaty Banning Nuclear Weapon Tests in the Atmosphere, in Outer Space and Under Water, w skrócie Limited Test Ban Treaty - LTBT), podpisany 5 VIII 1963 r., wszedl w życie 10 X 1963 r. 
W szczególności ma on znaczenie jako instrument regulujący podstawowe zasady wykorzystania przestrzeni kosmicznej, determinując także w dużej mierze obecną rolę kosmosu w bezpieczeństwie międzynarodowym. Omówimy go zatem w pierwszej kolejności, a następnie pokrótce inne akty prawne.

\section{Traktat o przestrzeni kosmicznej z 1967 roku}

OST $^{18}$ zorientowany jest bardzo wyraźnie na bezpieczeństwo międzynarodowe, już w preambule podkreślając kilkakrotnie, że przestrzeń kosmiczna ma być wykorzystywana pokojowo i w ramach międzynarodowej wspólpracy. Jej eksploracja i użytkowanie mają być realizowane dla dobra calej ludzkości i wszystkich krajów, bez względu na ich aktualny rozwój ekonomiczny i technologiczny.

Zapisy te precyzują trzy pierwsze artykuly, stanowiąc, że przestrzeń kosmiczna, Księżyc oraz pozostałe ciała niebieskie są domeną całej ludzkości (the province of all mankind), a ich badanie i wykorzystywanie ma odbywać się wedle wspomnianej powyżej zasady powszechnego dostępu. W związku z tym caly kosmos i cała powierzchnia ciał niebieskich są w pełni dostępne dla każdego i mogą być swobodnie badane i wykorzystane w zgodzie z prawem międzynarodowym - szczególnie mocno podkreśla się nieskrępowanie badań naukowych. Przestrzeń kosmiczna, Księżyc i inne ciała niebieskie nie mogą być zatem przedmiotem rozciągnięcia suwerenności państwowej, co w sposób względnie jasny określa, że kosmos należy traktować jako res communis, instytucję znaną i dobrze zadomowioną w prawie międzynarodowym.

O militarnym wykorzystaniu przestrzeni kosmicznej, Księżyca i ciał niebieskich traktuje art. IV. Zabrania on umieszczania baz wojskowych, umocnień $i$ innych instalacji militarnych na Księżycu i innych ciałach niebieskich, nie wolno tam także testować jakiejkolwiek broni ani prowadzić manewrów wojskowych. Całkowitym zakazem umieszczania i stacjonowania objęta jest broń masowego rażenia. Traktat zezwala natomiast na wykorzystanie personelu wojskowego w ramach badań naukowych oraz do innych pokojowych celów.

Kolejne artykuły zawierają ogólne reguly wykorzystania przestrzeni kosmicznej. I tak art. V stwierdza, że astronauci są wysłannikami całej ludzkości, a wszystkie

18 Omówienia traktatu OST oraz pozostałych źródel prawa kosmicznego dokonujemy na podstawie tekstów oryginalnych, zwartych w cytowanej powyżej publikacji UNOOSA, International Space Law: United Nations Instruments, polski tekst OST w: ${ }_{n}$ Dziennik Ustaw" 1968, nr 14, poz. 82, http://dziennikustaw.gov.pl/du/1968/s/14/82 lub http://ibr.sejm.gov.pl/tek01/oxt/onz/1967a.html, 3 II 2018. 
kraje mają udzielać im pomocy bez względu na narodowość. W kolejnym ustala się jako podstawową regułę odpowiedzialność państwa za jego działalność w kosmosie, zarówno prowadzoną przez państwowe agencje, jak i instytucje nienależące do rządu. W tym ostatnim przypadku ustala się konieczność uzyskiwania stosownych zezwoleń i prowadzenia stałego nadzoru ze strony państwa będącego stroną traktatu. Artykuł VII nakłada na kraj, który dokonuje wystrzelenia jakiegokolwiek obiektu w przestrzeń kosmiczną lub zleca je, oraz na państwo, z którego terytorium lub urządzenia start się odbyl, odpowiedzialność za szkody związane z tą procedurą. I wreszcie art. VIII stanowi, że państwo, które rejestruje obiekt kosmiczny, zachowuje jurysdykcję i kontrolę nad nim oraz jego personelem zarówno w przestrzeni kosmicznej, na Księżycu lub innym ciele niebieskim, jak i w przypadku, kiedy znajdzie się on na Ziemi poza granicami danego państwa - w tym wypadku traktat nakłada obowiązek zwrotu takiego obiektu państwu rejestracji.

Kolejne artykuły, od IX do XII, ustanawiają reguły współpracy międzynarodowej w procesie eksploracji i wykorzystania kosmosu. Według ich postanowień badanie i wykorzystanie przestrzeni kosmicznej, Księżyca i ciał niebieskich ma przebiegać zgodnie z zasadą współpracy i wzajemnej pomocy, a państwa mają kształtować swą aktywność w taki sposób, aby nie szkodzić działalności innych oraz nie doprowadzać do zanieczyszczenia środowiska naturalnego w kosmosie oraz na Ziemi. Zachęca się także, aby strony traktatu na zasadzie wzajemności godzily się na obserwację przez inne kraje swojej pozaziemskiej aktywności. Państwa działające w przestrzeni kosmicznej, na Księżycu i innych ciałach niebieskich powinny także informować w możliwie jak najszerszym zakresie ONZ oraz międzynarodową opinię publiczną i społeczność naukową o naturze, miejscu i przebiegu takiej działalności. Ustanawia się ponadto zasadę swobodnego dostępu przedstawicieli państw stron traktatu do instalacji i obiektów kosmicznych innych państw stron. Inspekcje tego typu są możliwe na zasadzie wzajemności, z zachowaniem ustalonych procedur notyfikacji i zasad bezpieczeństwa.

Pozostałe artykuły OST, od XIII do XVII, zawierają postanowienia końcowe, typowe dla umowy międzynarodowej. Według nich traktat jest bezterminowy, otwarty dla wszystkich państw, podlega ratyfikacji i może zostać zmodyfikowany w określonym trybie. Istnieje także możliwość wycofania się z niego po upływie jednego roku po notyfikacji takiego zamiaru.

Według stanu na dzień 1 I 2018 r. postanowieniami traktatu związanych jest 107 państw, a 23 kolejne są jego sygnatariuszami ${ }^{19}$ - nie jest to zatem porozumienie

19 Status of International Agreements relating to activities in outer space as at 1 January 2018, COPUOS, 9 IV 2018, http://www.unoosa.org/documents/pdf/spacelaw/treatystatus/AC105_C2_2018_CR- 
powszechne w dosłownym znaczeniu. Ponieważ jednak implementowały go wszystkie kraje prowadzące działalność kosmiczną, można go uznać w praktyce za źródło powszechnie obowiązującego prawa międzynarodowego.

Postanowienia OST są zatem bardzo doniosłe jako podstawa calego reżimu prawa kosmicznego. Warto jednak zwrócić uwagę, że traktat ustala bardzo proste i ogólne zasady, wystarczające w sytuacji, kiedy przestrzeń kosmiczna była jeszcze słabo wykorzystana, w zasadzie jedynie przez dwa supermocarstwa. Można wręcz powiedzieć, że strony postanowily ustanowić modus vivendi w podstawowych sprawach, natomiast uregulowania bardziej szczegółowe pozostawiono na czas późniejszy - kiedy rozwiną się środki i metody wykorzystywania przestrzeni kosmicznej. Everett Dolman podsumowuje to następująco:

Dla przesiąkniętych tradycją polityki równowagi sił i politycznej intrygi mężów stanu praktyczna wartość uznania przestrzeni kosmicznej za dziedzictwo całej ludzkości była oczywista. Bogactwa kosmosu i pełnia korzyści wynikających $\mathrm{z}$ kontroli nad nim były nieznane, a zatem skoro żadne $z$ supermocarstw nie było pewne przyszlych możliwości drugiego, wydawało się rozsądne, by zrobić wszystko, co możliwe, by uniemożliwić przeciwnikowi osiągnięcie dominacji. Mówiąc ściślej, ogłoszono, że kosmos jest niepodzielną domeną wszystkich ludów, jednocześnie pracując nad technologicznymi środkami i prawnymi uzasadnieniami służącymi zdobyciu nad nim kontroli. Retoryka kosmicznej współpracy była zatem przykrywką, by zyskać na czasie. Natomiast dla mających ambicje kosmiczne krajów niebędących supermocarstwami było równie ważne, aby utrzymać otwarte pole gry do czasu, aż będą zdolne zająć w niej korzystne dla siebie pozycje ${ }^{20}$.

Do tej oceny dodać należy, że swoista „prowizorka legislacyjna” utrzymała się po dziś dzień, a optymizm dotyczący możliwości zdobycia przez poszczególne państwa stałych strategicznych pozycji w przestrzeni okołoziemskiej okazal się zdecydowanie na wyrost. Luźna formuła traktatu stała się zatem przyczyną jego trwałości w tym sensie, że jest on $w$ zasadzie powszechnie przestrzegany. Jego istotną cechą z punktu widzenia bezpieczeństwa międzynarodowego jest to, że nie zabrania tworzenia broni kosmicznej, pod warunkiem że jest to broń konwencjonalna. W praktyce oznacza to pozostawienie możliwości skonstruowania broni przeciwsatelitarnej, która faktycznie powstała w latach $80 . \mathrm{XX}$ w., ale pozostała w fazie prototypów.

P03E.pdf, 16 IX 2018.

20 E. C. Dolman, Astropolitik. Classical Geopolites in the Space Age, London 2002 (Kindle Edition 2005), s. 166. 


\section{Inne akty prawne}

Wymienione porozumienia o ratownictwie kosmicznym, odpowiedzialności i rejestracji stanowią w gruncie rzeczy rozwinięcie postanowień OST, czego w niniejszej pracy nie ma potrzeby omawiać. Zostały one przyjęte przez znaczną liczbę państw, w tym wszystkie ważne dla wykorzystania przestrzeni kosmicznej ${ }^{21}$. Można zatem przyjąć, że stanowią źródło powszechnie obowiązującego prawa międzynarodowego.

Tymczasem Traktat księżycowy, który w zamyśle mial dalej konkretyzować i rozwijać OST, nie stanowi powszechnie obowiązującego prawa. Niewielka liczba ratyfikacji powoduje, że jest wiążący dla bardzo wąskiego grona niezbyt istotnych z punktu widzenia rozwoju kosmicznej eksploracji państw. Najistotniejsze jego punkty dotyczą badania oraz użytkowania powierzchni Księżyca i innych ciał niebieskich, a przede wszystkim kwestii eksploatacji ich zasobów.

Traktat księżycowy powtarza zasadniczą idę̨ OST, że korzyści z eksploatacji ciał niebieskich będących wspólnym dobrem ludzkości winny dotyczyć wszystkich państw świata, niezależnie od ich rozwoju ekonomicznego i technologicznego. Idzie jednak znacznie dalej niż poprzednik, ponieważ ustanawia obowiązek utworzenia międzynarodowego reżimu wyposażonego w odpowiednie procedury, który regulowałby kwestie dotyczące wydobycia surowców, kiedy tylko stanie się to w sensie technicznym możliwe. Zawiera ponadto ważne postanowienia uszczególawiające i rozwijające zakaz podnoszenia praw suwerennych lub zgłaszania prawa własności, przewidziany w art. 2 OST. Artykuł 11 MOON expressis verbis stanowi, że jakiekolwiek podmioty prywatne czy też publiczne nie mogą zgłaszać takich roszczeń w stosunku do przestrzeni kosmicznej, ciał niebieskich oraz bogactw naturalnych na nich się znajdujących.

Inaczej mówiąc, wedle Traktatu księżycowego prawo do eksploatacji przestrzeni kosmicznej nie oznacza automatycznie własności wydobytych surowców. Te mają być dzielone pomiędzy sygnatariuszy traktatu niezależnie od ich wkładu i poniesionych kosztów. Everett Dolman zwraca uwagę, że takie ujęcie jest skrajnie niekorzystne dla państw rozwiniętych, zmieniając w sposób fundamentalny interpretację istotnych zasad prawa międzynarodowego.

Traktat ten został okrzyknięty pierwszym aktem prawa kosmicznego nowej generacji, ponieważ reprezentuje sobą fundamentalną zmianę definicji res communis z tradycyjnej,

21 Status of International Agreements relating to activities in outer space as at 1 January 2016, Committee on the Peaceful Uses of Outer Space, United Nations, 4 IV 2016, http://www.unoosa.org/ documents/pdf/spacelaw/treatystatus/AC105_C2_2016_CRP03E.pdf, 22 VIII 2016. 
zbudowanej wokół zachodniej idei ${ }_{n}$ równego dostępu" na idę̨ ${ }_{n}$ równych korzyści" wyznawaną przez były blok radziecki i kraje rozwijające się

Wspomniano także o konwencjach szczególowych regulujących wspólpracę międzynarodową w dziedzinie telekomunikacji, które mniej lub bardziej dotyczą kwestii wykorzystania kosmosu. Konwencji takich jest 10, poczynając od porozumienia ustanawiającego Międzynarodową Unię Telekomunikacyjną, poprzez konwencje dotyczące regionalnej współpracy satelitarnej, a skończywszy na traktatach ustanawiających międzynarodowe agencje kosmiczne.

Niejako na marginesie warto dodać, że w 1976 r. siedem państw równikowych: Kongo, Zair (dziś Demokratyczna Republika Konga - DRK), Kenia, Uganda, Indonezja, Ekwador i Kolumbia, z Brazylią jako obserwatorem, ogłosiło tzw. Deklarację z Bogoty ${ }^{23}$. Ustanawia ona suwerenność tych krajów nad fragmentami rozciągającej się ponad ich terytorium orbity geostacjonarnej. Jednak Kenia, Brazylia, Ekwador i Uganda ratyfikowały OST, a Kolumbia, Indonezja i DRK go podpisały, co znacznie osłabia wymowę tego roszczenia. Pozostaje ono jednak w mocy, zapewne jako swego rodzaju argument przetargowy w ramach konstruowania ewentualnego przyszłego reżimu prawa kosmicznego ${ }^{24}$.

\section{Prawo kosmiczne współcześnie - stan obecny i perspektywy}

\section{rozwoju w kontekście bezpieczeństwa międzynarodowego}

Jak wynika z powyższych rozważań, dorobek prawa kosmicznego jest relatywnie szczuply w porównaniu do innych dziedzin prawa międzynarodowego. Wynika to z bardzo wielu czynników, ale przede wszystkim $z$ tego, że obecność czlowieka w przestrzeni kosmicznej wciąż jest nieznaczna. Poszczególne państwa, w tym mocarstwa kosmiczne, nie wyobrażały sobie ściślejszego i bardziej szczególowego reżimu prawnego, ponieważ nie były pewne ani swoich przyszłych możliwości techniczno-organizacyjnych, ani długofalowych interesów $z$ nich wynikających. W związku z tym słabe i giętkie uregulowania do niedawna jeszcze w zupełności wystarczały. Ustalały bowiem jedynie podstawowe zasady niezbędne do prawidłowego funkcjonowania stosunków mię-

22 E. C. Dolma n, op. cit., s. 133.

23 Pelna nazwa: Declaration of the First Meeting of Equatorial States. Adopted on December 3, 1976, https://bogotadeclaration.wordpress.com/declaration-of-1976/, 7 II 2018.

24 F. Lyall, P. B. Larsen, Space Law, London-New York 2016, s. 253-256. 
dzypaństwowych w odniesieniu do przestrzeni kosmicznej, calą resztę ewentualnych problemów pozostawiając otwartą.

Przykładem może być, fundamentalna skądinąd, kwestia granicy pomiędzy przestrzenią kosmiczną a powietrzną, której przebieg wciąż nie został ustalony. $Z$ istniejących przepisów można jedynie wnioskować jej istnienie, ponieważ inny reżim prawny został ustalony dla kosmosu, a inny dla przestrzeni powietrznej. Taki stan rzeczy na razie nie jest większym problemem, ponieważ, jak wspomniano, działalność kosmiczna, czyli na orbicie okołoziemskiej, zaczyna się od mniej więcej $200 \mathrm{~km}$ od powierzchni Ziemi, a działalność w powietrzu, poza małymi wyjątkami, kończy się na 20-25 km. Tak więc istnieje szeroka granica możliwości wynikająca z technologii, jakimi dysponuje ludzkość, nie było zatem potrzeby tworzenia szczególowej regulacji. Przyjmuje się zatem, choć nie jest to prawnie wiążące, że granica przestrzeni kosmicznej to $100 \mathrm{~km}$ nad ziemią. Jest to wartość czysto teoretyczna, wywodzi się z zaproponowanej przez Theodore'a von Kármána koncepcji zakładającej, że kosmos to ta przestrzeń, w której obiekt atmosferyczny, aby utrzymać siłę nośną, musi poruszać się tak szybko, że osiąga prędkość orbitalną, przez co staje się satelitą i nie wymaga napędu. Jest to dziś jedyny, oparty na prawach fizyki, punkt odniesienia, nie musi być jednak właściwy $z$ innych perspektyw. Stąd wlaśnie ustawodawstwo większości państw nie zawiera nawet wzmianki na ten temat, inne zaś deklarują ogólną zgodę na zasadę von Kármána, podkreślając, że szczególy zależą od kwestii technicznych i przyszlego rozwoju technologii ${ }^{25}$. Tymczasem $z$ punktu widzenia bezpieczeństwa granica, jej przebieg i jej ochrona ma podstawowe znaczenie, a w miarę pojawiania się nowych technologii obecny stan zawieszenia w tej kwestii może stać się niewystarczający. Płynność i niejasność reguł może nawet prowadzić do konfliktów i napięć z trudnymi do przewidzenia konsekwencjami.

W ostatnich dwóch dekadach nastąpiła jednak znaczna ewolucja zastosowań kosmicznych oraz zmiany w środowisku bezpieczeństwa kosmicznego rozumianego jako część bezpieczeństwa międzynarodowego. Jako najważniejsze można wymienić:

- osiągnięcie przez ChRL pozycji de facto supermocarstwa kosmicznego; wprawdzie Chiny nie są tak zaawansowane technicznie jak Rosja, a tym bardziej jak USA, niemniej jednak dysponują znacznymi funduszami, większymi wyraźnie niż rosyjskie, są także $z$ wielu powodów zdecydowane inwestować $\mathbf{w}$ przedsięwzięcia kosmiczne - stąd szybki postęp w tej materii;

25 Por. np. stanowisko Austrii z 2017 r., w: Definition and delimitation of outer space: views of States members and permanent observers of the Committee. Austria, COPUOS, 3 III 2017, http://www. unoosa.org/oosa/oosadoc/data/documents/2017/aac.105/aac.1051112add.3_0.html, 19 I 2018. 
- upowszechnienie technologii związanych $z$ umieszczaniem ładunków na orbicie okołoziemskiej oraz z lotami suborbitalnymi; kolejne państwa pracują nad tego typu możliwościami, pojawiły się także liczne przedsiębiorstwa prywatne działające $w$ tej dziedzinie, w kolejce jest wiele dalszych ${ }^{26}$;

- technika satelitarna rozpowszechniła się tak dalece, że stała się bez mała niezbędna do funkcjonowania globalnej gospodarki, jest także przedmiotem powszechnego użytku społeczeństw - w najbliższym czasie należy spodziewać się dalszego przyspieszenia w tej dziedzinie ${ }^{27}$, rozwiną się nowe obszary zastosowań kosmicznych, takie jak turystyka, produkcja, pozyskiwanie surowców;

- coraz więcej krajów dysponuje środkami satelitarnymi, które można zastosować na potrzeby bezpieczeństwa narodowego ${ }^{28}$; zwiększa się ponadto dostępność komercyjnych usług, które mogą być wykorzystane przez kolejne państwa i uczestników niepaństwowych w ramach ich działań mających wplyw na bezpieczeństwo międzynarodowe;

- upowszechniają się możliwości negatywnego oddziaływania na systemy satelitarne: zakłócanie, przejmowanie kontroli, oślepianie, niszczenie obiektów orbitalnych; państwa dysponujące odpowiednio rozwiniętą techniką rakietową mogą pokusić się o skonstruowanie systemów przeciwsatelitarnych - zatem już tylko glówne mocarstwa mogą oddziaływać negatywnie na systemy kosmiczne; należy także spodziewać się rozwoju tych możliwości;

- narasta zagrożenie dla naturalnego środowiska przestrzeni okołoziemskiej związane z postępującym jej zaśmieceniem; może to w konsekwencji doprowadzić do degradacji przynajmniej niektórych orbit i ograniczyć możliwości dostępu do kosmosu i jego wykorzystania;

- rozwój technologii nieuchronnie przybliża perspektywę skonstruowania pojazdów, które będą mogły względnie swobodnie manewrować pomiędzy przestrzenią kosmiczną a atmosferą lub też w górnych jej warstwach.

Taka ewolucja środowiska bezpieczeństwa nie tylko uwypukla rolę przestrzeni kosmicznej, ale także obnaża słabość prawa kosmicznego. W ciągu dekady lub dwóch

26 Na przykład w 2021 r. loty suborbitalne ma zaoferować przedsiębiorstwo Space Forest z Gdyni, por. Space Projects, https://spaceforest.pV/portfolio/space-projects/, 21 I 2018.

27 Na przykład przedsiębiorstwo OneWeb zamierza pomiędzy r. 2018 a 2027 wprowadzić na niskie orbity konstelację kilkuset satelitów, które mają zapewnić globalny dostęp do szerokopasmowego Internetu, por. Satellites Make it All Possible, http://www.oneweb.world/\#solution, 21 I 2018.

28 Wedlug stanu na dzień 31 VIII 2017 r. 22 kraje posiadaly obiekty satelitarne zarejestrowane jako wojskowe, w tym np. Zjednoczone Emiraty Arabskie, Meksyk i Chile, za: UCS Satellite Database, Union of Concerned Scientists, https://www.ucsusa.org/nuclear-weapons/space-weapons/ satellite-database\#.WmRZEDSDOt8, 21 I 2018. 
pewne regulacje będą wręcz niezbędne, aby uniknąć chaosu i potencjalnie niebezpiecznej polityki faktów dokonanych. Glówne problemy, których rozwiązanie jest konieczne dla zachowania bezpieczeństwa kosmicznego, a zatem ważne również dla stabilności "ziemskiego" bezpieczeństwa, to:

- wasność surowców pozyskanych w kosmosie; w 2015 r. rząd USA jednostronnie uregulował tę kwestię, przyznając to prawo podmiotom wydobywczym ${ }^{29}$, lecz nie ma to odniesienia w prawie międzynarodowym ${ }^{30}$, jest zatem zarzewiem poważnego wielopłaszczyznowego sporu;

- podzial dostępu do potencjalnie wartościowych z punktu widzenia gospodarczego lokalizacji na ciałach niebieskich oraz atrakcyjnych punktów w przestrzeni lub obszarów na orbitach, takich jak punkty libracyjne ${ }^{31}$ czy orbita geostacjonarna;

- granica pomiędzy przestrzenią kosmiczną uznawaną za res communis a przestrzenią powietrzną podlegającą suwerenności państwowej;

- niezwykle ważka kwestia doprecyzowania uregulowań dotyczących wojskowego zastosowania przestrzeni kosmicznej, w tym broni kosmicznych oraz broni $\mathrm{i}$ innych oddziaływań przeciwsatelitarnych.

Istotnym czynnikiem powyższych zmian jest także międzynarodowa konkurencja, mająca zarówno materialne, jak i prestiżowe podstawy. Te ostatnie utrudniają dochodzenie do kompromisu, który będzie musiał zostać zawarty pomiędzy trzema glównymi mocarstwami kosmicznymi. Stwarza to bardzo niestabilną sytuację negocjacyjną, dodatkowo skomplikowaną wskutek istnienia mocarstw drugorzędnych, takich jak Francja, jako państwo wiodące w Europejskiej Agencji Kosmicznej, Japonia czy Indie. Kolejnym utrudnieniem jest duże prawdopodobieństwo, że Stany Zjednoczone będą niechętne rozszerzeniom regulacji kosmicznych, a bez tego kraju jakiekolwiek ewentualne traktaty będą niekompletne lub nieskuteczne. W USA często pojawiają się głosy, że uszczegółowienie zasad prawa kosmicznego mogłoby:

- ograniczyć możliwości wykorzystania kosmosu do celów bezpieczeństwa, przede wszystkim poprzez zamknięcie drogi do przyszłych, potencjalnie rewolucyjnych technologii, które USA mogłyby opracować jako pierwsze i użyć do poglębienia swojej przewagi;

29 Space Resource Exploration and Utilization Act of 2015, U.S. Congress, 2015, https://www.govtrack us/congress/bills/114/s976, 6 II 2018.

30 A. Basu, A. Kurlekar, Highway to the Danger Zone: United States Legislative Framework Regulating the Commercial Space Sector, ${ }_{n}$ Astropolitics" 2016, t. 14, nr 1, s. 59-60, https://doi.org/10.1 080/14777622.2016.1149382, 6 II 2018.

31 Obszary, w których grawitacja ciał niebieskich się równoważy, gdzie zatem można umieszczać obiekty, które będą względnie trwale utrzymywały swoją pozycję. 
- zmniejszyć domniemaną amerykańską hegemonię w kosmosie, która ma wielkie znaczenie nie tylko praktyczne, ale także polityczne i prestiżowe;

- podnieść status i zdolność do ograniczania pola manewru USA i innych państw, a szczególnie Chin, postrzeganych jako główny konkurent, który w przyspieszonym tempie niweluje przewagę USA w różnych dziedzinach.

Jak widać, Stany Zjednoczone mogą obawiać się utraty swojej pozycji jako bezsprzecznie największego dziś mocarstwa kosmicznego, a także ograniczenia kluczowych zdolności w zakresie bezpieczeństwa narodowego. Na przykład cytowany wielokrotnie Everett Dolman w swojej klasycznej pozycji Astropolitik sugeruje nawet wypowiedzenie OST przez USA i zastąpienie go zupełnie innym reżimem prawnym, który umożliwiałby zglaszanie prywatnych roszczeń do surowców i powierzchni ciał niebieskich. Tym sposobem USA, wyzbyte niewygodnych ograniczeń, mogłyby skorzystać ze swojej przewagi i ustanowić faktyczną hegemonię w kosmosie ${ }^{32}$.

Podsumowując, wyścig kosmiczny ewoluuje i komplikuje się, a rozwój technologii może wkrótce wymusić szczególowe rozwiązania, zarówno dotyczące podstawowych definicji, takich jak delimitacja przestrzeni kosmicznej, jak i kwestii szczególowych związanych z rozwojem technologï wykorzystywanych militarnie oraz ich wplywem na bezpieczeństwo narodowe i międzynarodowe. Jednocześnie istnieje szereg politycznych przeszkód, które mogą utrudnić rozwój prawa kosmicznego.

\section{Stan i perspektywy militaryzacji kosmosu}

W pierwszej kolejności należy zauważyć, że „[...] militarna technologia kosmiczna jest problematyką szeroką i zróżnicowaną w swej naturze, co utrudnia jednolitą kategoryzację"33. Najogólniej rzecz ujmując, współczesne wojskowe zastosowania przestrzeni kosmicznej sprowadzają się do zabezpieczania procesu przygotowania oraz ewentualnego prowadzenia działań zbrojnych. Obejmują zatem nie tylko aplikacje należące do sił zbrojnych, ale również inne związane $z$ bezpieczeństwem narodowym w wymiarze zewnętrznym, a także zastosowania systemów cywilnych, których można użyć do wsparcia sfery wojskowej. Definiując militaryzację kosmosu, powinniśmy zatem odwoływać się do ujęcia funkcjonalnego, wskazując na zadania wykonywane przez określone systemy. A zatem militaryzacja bierna będzie to zastosowanie syste-

32 E. C. Dolman, op. cit., s. 171-174.

33 G. Seriak, Between a Rocket and a Hard Place: Military Space Technology and Stability in International Relations, ,Astropolitics” 2017, t. 15, nr 1, s. 52, https://doi.org/10.1080/14777622.2017. 1288509, 6 II 2018. 
mów kosmicznych dla wsparcia procesu przygotowania i ewentualnego prowadzenia działań zbrojnych przez państwa oraz podmioty niepaństwowe.

Militaryzacja bierna kosmosu oznacza w szczególności wykorzystywanie wojskowych lub cywilnych systemów satelitarnych w czasie pokoju oraz w trakcie prowadzenia działań zbrojnych do:

- zbierania informacji w postaci generowanych obrazów lub zapisu przechwyconych transmisji elektromagnetycznych;

- realizowania zadań w zakresie lączności we wszystkich zakresach pasma elektromagnetycznego;

- ustalania pozycji obiektów naziemnych;

- prowadzenia badań naukowych nad zastosowaniami militarnymi.

$\mathrm{Z}$ powyższego wynika, że współcześnie militarne zastosowania przestrzeni kosmicznej służą w zasadzie wyłącznie jako force multiplier ${ }^{34}$. Dla porządku należy jeszcze dodać, że kosmos może stać się polem walki w sytuacji starcia systemów obrony przeciwrakietowej z tymi balistycznymi pociskami rakietowymi, które w trakcie lotu do celu będą się poruszać w przestrzeni kosmicznej.

Drugi stopień militaryzacji kosmosu to militaryzacja czynna, przy czym w literaturze anglojęzycznej używa się bardzo adekwatnego pojęcia weaponization ${ }^{35}$. Oznacza to pojawienie się systemów służących do prowadzenia walki zbrojnej w kosmosie, które można najogólniej podzielić na dwie kategorie. Pierwsza to broń przeznaczona do walki z obiektami naziemnymi, czyli do swego rodzaju bombardowania kosmicznego. Druga to systemy przeznaczone do niszczenia innych obiektów satelitarnych, nazywane bronią przeciwsatelitamą, występującą często pod skrótem ASAT ${ }^{36}$.

Pierwszy rodzaj broni kosmicznej znany jest od dawna jako teoretyczna koncepcja. Już w latach 50. XX w. przewidywano, że ze względu na charakterystykę przestrzeni kosmicznej będzie ona się świetnie nadawała do umieszczania w niej broni ofensywnej, co miało nastąpić względnie szybko. Rzeczywistość jednak okazała się inna, broń tego typu nie jest bowiem zbyt praktyczna, a jednocześnie jej ewentualne rozmieszczenie pociągałoby za sobą ogromne koszty. Nie wchodząc w szczegóły techniczne, można stwierdzić, że balistyczne pociski rakietowe dużego zasięgu są znacznie tańszą i bardziej wiarygodną, a więc praktyczną altematywą. Dopiero pojawienie się technologii samolotu kosmicznego, który mógtby szybko wystartować i swobodnie manewrując,

34 Trudne do przetumaczenia pojęcie oznaczające wysiłek zwielokrotniający skuteczność działań.

35 Pojęcie to wywodzi się od slowa weapon, czyli 'broń, uzbrojenie'. Oznacza zatem w luźnym przekładzie "wyposażenie w brońn.

36 Skrót od: Anti-Satellite. 
zająć dogodną do uderzenia naziemnego pozycję, mogłoby zmienić ten stan rzeczy, ale to jest wciąż jeszcze science fiction.

O wiele bardziej użyteczna w sensie wojskowym może być broń przeciwsatelitarna i to jej ewentualne rozprzestrzenienie się może mieć praktyczne znaczenie z punktu widzenia bezpieczeństwa międzynarodowego, a zatem i w perspektywie prawa międzynarodowego. Ponownie unikając szczególów technicznych, ASAT w praktyce odnosi się do systemów zestrzeliwania" satelitów przez startujące z Ziemi pociski rakietowe, a w nieodległej zapewne perspektywie przez naziemne lasery. Takie systemy zostały opracowane jeszcze w czasie zimnej wojny przez USA i ZSRR, a prototypami takiego uzbrojenia dysponują także Chiny. Oprócz tego istnieje ewentualność, że wkrótce technologia ASAT pojawi się w arsenalach innych państw, co byłoby szczególnie destabilizujące w sytuacji, kiedy nie miałyby one kluczowych interesów w kosmosie mogłyby zatem $w$ ramach asymetrycznego odstraszania traktować jako zakładnika ważne dla mocarstw systemy kosmiczne ${ }^{37}$.

Istnieje rozpowszechniony pogląd, osadzony mocno w realistycznej perspektywie badawczej, że upowszechnienie się broni przeciwsatelitarnej jest nieuchronne ${ }^{38}$. Argumentuje się przede wszystkim, że skoro rozpowszechniają się odpowiednie możliwości techniczne, prędzej czy później jakieś państwo lub może nawet uczestnik niepaństwowy skonstruuje i rozmieści odpowiednie systemy z zamiarem stworzenia zagrożenia dla przeciwników lub bezpośredniego zaszkodzenia im. Jest to jak najbardziej prawidlowa konstatacja, szczególnie że potencjalnych twórców broni kosmicznej jest wielu, nie ma zatem stabilnego układu wzajemnego odstraszania, jaki panował w czasie zimnej wojny pomiędzy dwoma względnie równorzędnymi przeciwnikami. Ponadto systemy ASAT mogą potencjalnie dość latwo ograniczyć globalną przewagę militarną USA, która w pewnej mierze wynika z powszechnego zastosowania systemów kosmicznych dla wsparcia sil zbrojnych. W tym kontekście częstokroć wskazuje się na to, że Rosja i ChRL faktycznie dążą do stworzenia systemów bojowych ASAT właśnie w celu zagrożenia amerykańskiej przewadze w kosmosie ${ }^{39}$.

Patrząc jednak na sprawę z szerszej perspektywy, można dostrzec inny wariant przyszłego rozwoju sytuacji. Rosnące prawdopodobieństwo upowszechnienia się broni

37 G. Seriak, op. cit., s. 60.

38 Por. np.: E. C. Dolma n, H. F. Cooper, Jr., Increasing the Military Uses of Space. Selected Essays, [w:] Toward a Theory of Spacepower, red. C. D. Lutes, P. L. Hays, Washington 2011, s. 373-390, http://www.dtic.mil/dtic/tr/fulltext/u2/a546585.pdf, 24 VII 2014.

39 M. Dura, Nadchodzi wojna w kosmosie? Chiny i Rosja zagrożeniem dla amerykañskich satelitów,

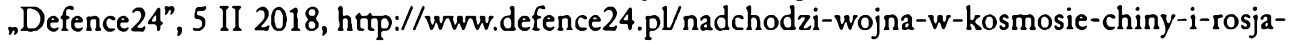
zagrozeniem-dla-amerykanskich-satelitow, 7 II 2018. 
przeciwsatelitarnej może bowiem pchnąć główne mocarstwa kosmiczne w kierunku pogłębienia regulacji w zakresie prawa kosmicznego. W szczególności może to dotyczyć właśnie ograniczenia proliferacji bądź nawet delegalizacji systemów ASAT.Taka sytuacja może nastąpić, jeśli najbardziej zainteresowane kraje uświadomią sobie, że w tej kluczowej sprawie ich interesy są zbieżne, nawet mimo konkurencji czy wręcz wrogości $w$ innych kwestiach.

Trzeba bowiem pamiętać, że wszystkie mocarstwa kosmiczne w coraz większym stopniu są uzależnione od systemów kosmicznych w ramach realizacji zadań z zakresu bezpieczeństwa narodowego, które zostały wymienione powyżej. Zainteresowane są zatem żywotnie podtrzymaniem możliwości korzystania $z$ nich przede wszystkim w trakcie pokoju. Zabezpieczenie pewności tego wykorzystania, właśnie w czasie pokoju, może być uznane za bardziej wartościowe od posiadania broni, dzięki której w razie kryzysu bądź konfliktu można by zniszczyć satelity przeciwnika. Kryzys taki może bowiem nie nastąpić, a wykorzystanie w czasie pokoju ma charakter ciągły i korzyści z niego także. Dzięki takiej właśnie logice broń przeciwsatelitarna nigdy nie została rozmieszczona - obie strony zimnej wojny wolały bowiem realne korzyści w postaci bezpieczeństwa i nieustannego działania systemów kosmicznych wspierających kluczowe zadania od iluzorycznych, bo warunkowanych zaistnieniem faktycznego konfliktu zbrojnego, korzyści w postaci zdolności do zniszczenia wrogiego systemu zabezpieczenia działań - co oznaczałoby zresztą praktycznie natychmiastową utratę własnego analogicznego systemu.

Drugi czynnik, który może sprzyjać porozumieniu w sprawie ograniczenia broni przeciwsatelitarnej, to rosnące komercyjne znaczenie sektora kosmicznego. Mamy tu do czynienia zarówno z ogromną liczbą przedsiębiorstw produkujących i dostarczających usługi na potrzeby sektora kosmicznego, jak i z odbiorcami tych zastosowań. Tymczasem użycie systemów ASAT, choćby tylko ograniczone, w ramach kryzysu nieprowadzącego do wojny może doprowadzić do świadomego bądź przypadkowego zniszczenia systemów cywilnych. Pociąga to za sobą lawinowy wzrost ilości kosmicznych śmieci, których nadmiar może zablokować niektóre orbity, a w skrajnym przypadku uniemożliwić w ogóle wykorzystywanie przestrzeni kosmicznej. Taki przebieg wydarzeń nie tylko doprowadziłby do ogromnych strat gospodarczych, ale także ograniczyłby lub całkowicie zlikwidował zdolności militarne, ważne szczególnie dla mocarstw kosmicznych.

Tym sposobem świadomość zagrożeń, także wynikających ze skutków niszczenia satelitów wychodzących poza zamierzenia użytkowników ASAT, może skłonić główne mocarstwa do podjęcia regulacji w tym zakresie. Oczywiście współcześnie o równowagę jest trudniej niż w przypadku systemu dwubiegunowego, lecz nie oznacza to niemo $\dot{z}-$ 
liwości osiągnięcia kompromisu przez mocarstwa, za którymi z konieczności podążą kolejne państwa. A zatem, paradoksalnie, rosnące prawdopodobieństwo powstania broni przeciwsatelitarnej może wpłynąć pozytywnie na zacieśnienie wspólpracy międzynarodowej i uszczegółowienie prawa kosmicznego. Najważniejszą przeszkodą będą w tym wypadku przesłanki o charakterze irracjonalnym, o których już wspomniano, szczególnie te leżące po stronie Stanów Zjednoczonych.

\section{Podsumowanie}

Wydaje się, że należy zgodzić się z poglądem, iż pojawia się dziś potrzeba pogłębienia regulacji prawa kosmicznego w kwestiach bezpieczeństwa międzynarodowego. W szczególności dotyczy to koniecznych ograniczeń w zakresie broni przeciwsatelitarnej oraz stworzenia realistycznych postanowień dotyczących eksploatacji surowców w kosmosie, których brak może prowadzić do napięć przenoszących się na sferę bezpieczeństwa. $\mathrm{Z}$ drugiej jednak strony nie można nie zauważyć tendencji do zaostrzenia konkurencji w przestrzeni kosmicznej związanej ze zwiększaniem się jej znaczenia i rozwojem technologii ułatwiających eksploatację i wykorzystanie cywilne oraz wojskowe.

Istnieją dziś, jak się zdaje, dwa podstawowe scenariusze dotyczące rozwoju prawa kosmicznego. Pierwszy z nich zakłada, że poszczególne państwa, a przede wszystkim mocarstwa, będą dążyć do maksymalizacji swoich zdolności w kosmosie, pozycjonując się w stosunku do przewidywanych korzyści, które wprawdzie dziś są jeszcze przyszłością, ale które w ciągu kilku dekad mogą stać się realne. W takiej sytuacji czeka nas nowy wyścig kosmiczny ze wszystkimi jego konsekwencjami, takimi jak napięcie, wyścig zbrojeń, a potencjalnie degradacja przestrzeni wokólziemskiej w wyniku konfliktu. Prawo kosmiczne nie rozwinie się w takich okolicznościach, a możemy nawet mieć do czynienia $\mathrm{z}$ jego regresem.

Drugi scenariusz przewiduje stopniowe dochodzenie do porozumienia w gtównych sprawach na gruncie wspólnego interesu państw, które z działalności w przestrzeni kosmicznej odnoszą największe korzyści. Mogą one dojść do wniosku, poniekąd analogicznie jak w latach 60. XX w., że ważniejsze jest zabezpieczenie obecnych, realnych korzyści, które mogą ucierpieć w wyniku konkurencji, notabene niewątpliwie bardzo kosztownej. W takich okolicznościach można spodziewać się stopniowego rozwoju prawa kosmicznego, a w szczególności ograniczenia dalszej militaryzacji kosmosu.

Nie sposób dziś przewidzieć, którą z wymienionych dróg podąży ludzkość w swym podboju kosmosu. Pozostaje mieć nadzieję, że historia się powtórzy i krótki okres 
gwałtownej konfrontacji zakończy wypracowanie kolejnego modus vivendi, tak jak się stało w pierwszej dekadzie ery kosmicznej.

\section{Bibliografia}

\section{Dokumenty}

Declaration of the First Meeting of Equatorial States. Adopted on December 3, 1976, https:// bogotadeclaration.wordpress.com/declaration-of-1976/, 7 II 2018.

International co-operation in the peaceful uses of outer space, Rezolucja ZO ONZ $\mathrm{nr} 1472$ (XIV), 12 XII 1959, http://www.unoosa.org/pdf/gares/ARES_14_1472E.pdf, 13 I 2017.

International co-operation in the peaceful uses of outer space, Rezolucja ZO ONZ $\mathrm{nr} 1721$ (XVI), 20 XII 1961, http://www.unoosa.org/pdf/gares/ARES_16_1721E.pdf, 13 I 2017.

International Space Law: United Nations Instruments, UNOOSA, May 2017.

Question of the peaceful use of outer space, Rezolucja ZO ONZ nr 1348 (XIII), 13 XII 1958, http://www.unoosa.org/pdf/gares/ARES_13_1348E.pdf, 13 I 2017.

Space Resource Exploration and Utilization Act of 2015, U.S. Congress, 2015, https://www. govtrack.us/congress/bills/114/s976, 6 II 2018.

Uktad o zasadach rzgdzqcych dzialalnosicia pañstw w ramach eksploracji $i$ wykorzystania przestrzeni kosmicznej, tqcznie z ksįżycem $i$ innymi cialami niebieskimi, "Dziennik Ustaw" 1968, nr 14, poz. 82.

\section{Monografie}

Dolman E. C., Astropolitik. Classical Geopolites in the Space Age, London 2002 (Kindle Edition 2005).

Lyall F., Larsen P. B., Space Law, London-New York 2016.

\section{Rozdzialy w pracach zbiorowych}

Dolman E. C., Cooper H. F. Jr., Increasing the Military Uses of Space. Selected Essays, [w:] Toward a Theory of Spacepower, red. C. D. Lutes, P. L. Hays, Washington 2011, http://www. dtic.mil/dtic/tr/fulltext/u2/a546585.pdf, 24 VII 2014.

\section{Artykuly w czasopismach naukowych}

Basu A., Kurlekar A., Highway to the Danger Zone: United States Legislative Framework Regulating the Commercial Space Sector, ${ }_{n}$ Astropolitics" 2016, t. 14, nr 1.

Seriak G., Between a Rocket and a Hard Place: Military Space Technology and Stability in International Relations, ${ }_{n}$ Astropolitics" 2017, t. 15, nr 1.

\section{Źródła internetowe}

Definition and delimitation of outer space: views of States members and permanent observers of the Committee. Austria, COPUOS, 3 III 2017, http://www.unoosa.org/oosa/oosadoc/data/ documents/2017/aac.105/aac.1051112add.3_0.html, 19 I 2018.

Dura M., Nadchodzi wojna w kosmosie? Chiny i Rosja zagrożeniem dla amerykańskich satelitów, „Defence24", 5 II 2018, http://www.defence24.pl/nadchodzi-wojna-w-kosmosie-chinyi-rosja-zagrozeniem-dla-amerykanskich-satelitow, 7 II 2018. 
Educational Curriculum on Space Law, UNOOSA, 2014, http://www.unoosa.org/res/oosadod data/documents/2014/stspace/stspace64_0_html/st_space_064E.pdf, 16 I 2018.

Satellites Make it All Possible, http://www.oneweb.world/\#solution, 21 I 2018.

Space Projects, https://spaceforest.pl/portfolio/space-projects/, 21 I 2018.

Space law, Encyclopaedia Britannica, 27 XII 2017, https://www.britannica.com/topic/spacelaw, 13 I 2018.

Status of International Agreements relating to activities in outer space as at 1 January 2016, Committee on the Peaceful Uses of Outer Space, United Nations, 4 IV 2016, http://www. unoosa.org/documents/pdf/spacelaw/treatystatus/AC105_C2_2016_CRP03E.pdf, 22 VIII 2016.

Status of International Agreements relating to activities in outer space as at 1 January 2017, COPUS, 23 March 2017, http://www.unoosa.org/documents/pdf/spacelaw/treatystatus/ AC105_C2_2017_CRP07E.pdf, 13 I 2018.

Status of International Agreements relating to activities in outer space as at 1 January 2018, COPUOS, 9 IV 2018, http://www.unoosa.org/documents/pdf/spacelaw/treatystatus/ AC105_C2_2018_CRP03E.pdf, 16 IX 2018.

UCS Satellite Database, Union of Concerned Scientists, https://www.ucsusa.org/nuclearweapons/space-weapons/satellite-database\#.WmRZEDSDOt8, 21 I 2018.

Ziarnick B., Garretson P., Starfleet was closer than you think, "The Space Review”, 16 III 2015, http://www.thespacereview.com/article/2714/1,16 IV 2015. 
